\title{
EPIDEMIOLOGIC STUDY ON THE REPRODUCTIVE LOSSES IN DAIRY CATTLE: OCCURRENCE OF Neospora caninum, Brucella abortus, BOVINE HERPESVIRUS TYPE-1 AND Leptospira spp. IN A FARM IN SÃO CARLOS, SP
}

\author{
ESTUDO EPIDEMIOLÓGICO SOBRE AS PERDAS REPRODUTIVAS EM BOVINOS \\ LEITEIROS: OCORRENNCIA DE Neospora caninum, Brucella abortus, HERPESVÍRUS BOVINO \\ TIPO-1 E Leptospira spp. EM UMA PROPRIEDADE \\ DO MUNICÍPIO DE SÃO CARLOS-SP
}

\author{
R. C. M. SANTANA ${ }^{1 *}$, R. MASSA ${ }^{2}$, L. F. ZAFALON ${ }^{1}$, J. MEGID ${ }^{3}$, H. LANGONI ${ }^{3}$, \\ L. A. MATHIAS ${ }^{2}$
}

\section{SUMMARY}

The aim of this work is to determine the endemic level of reproductive losses and positivity for four infectious agents related to reproductive problems in dairy cattle of a farm in São Carlos, SP, Brazil. Blood samples were collected from 142 animals at reproductive age, older than two years, $21.1 \%$ of which had a history of abortions or stillbirths in at least one pregnancy. Immunofluorescent assay test (IFAT), buffered acidified antigen test (BAAT), serum neutralization technique (SNT) and microscopic agglutination test (MAT) were used for the detection of anti-Neospora caninum, antiBrucella abortus, anti-Bovine Herpesvirus Type 1 (anti-BHV-1) and anti-Leptospira spp., respectively. The serological tests conducted showed that $28.9 \%$ of the animals had titers greater than or equal to 100 for anti-Neospora caninum. Viral neutralization tests demonstrated that $26.8 \%$ of the animals had titers greater or equal to 256 for anti-BHV-1. Only $7.7 \%$ of the studied animals had titers equal to or greater than 100 for Leptospira spp. in the microscopic agglutination test. Furthermore, no positive reactions were observed for the buffered acidified antigen test for the diagnosis of bovine brucellosis. The results suggest the presence of BHV-1, N. caninum and Leptospira spp. in contact with dairy cattle in the experimental farm, which could be responsible for the occurrence of abortions and stillbirths in the herd. Reproductive losses are endemic, thus implying the possible presence of chronic infections caused by these microorganisms.

KEY-WORDS: Cattle. Etiological agents. Reproduction.

\section{RESUMO}

Este trabalho objetivou traçar o nível endêmico de perdas reprodutivas e determinar a positividade para quatro agentes infecciosos relacionados com problemas reprodutivos em um rebanho bovino leiteiro no município de São Carlos-SP. Foram coletadas amostras de soro sanguíneo de 142 animais em reprodução com idades acima de dois anos, dos quais $21,1 \%$ apresentaram casos de abortamentos ou natimortos em pelo menos uma gestação. Utilizaram-se os testes sorológicos de imunofluorescência indireta, teste do antígeno acidificado tamponado, virusneutralização e soroaglutinação microscópica, virusneutralizaçãopara detecção de anticorpos anti-Neospora caninum, anti-Brucella abortus, anti-Herpesvírus Bovino Tipo-1(BoHV-1) e anti-Leptospira spp., respectivamente. Os exames sorológicos realizados demonstraram que $28,9 \%$ dos animais apresentaram títulos superiores ou iguais a 100 de anticorpos antiNeospora caninum. Os exames de virusneutralização demonstraram que 26,8\% dos animais apresentaram títulos maiores ou iguais a 256 para anticorpos anti-BoHV-1. Apenas 7,7\% dos animais estudados apresentaram títulos iguais ou superiores a 100 na soroaglutinação microscópica para diagnóstico de Leptospira spp. Não foram observadas reações positivas ao teste de antígeno acidificado tamponado para diagnóstico de brucelose bovina. O estudo realizado sugere a presença de BoHV-1, N. caninum e Leptospira spp. em contato com os animais leiteiros da unidade experimental, podendo estar envolvidos na ocorrência de abortamentos e natimortos no rebanho. As perdas reprodutivas encontram-se de forma endêmica, implicando um possível comportamento crônico das infecções causadas por estes microorganismos.

PALAVRAS-CHAVE: Bovinos. Agentes etiológicos. Reprodução.

\footnotetext{
1*EMBRAPA Pecuária Sudeste. Rua José Rodrigues, nº177, ZIP 13.560-710, São Carlos-SP. Corresponding author: raul.mascarenhas@embrapa.br

${ }^{2}$ Universidade Estadual Paulista - UNESP - FCAV

${ }^{3}$ Universidade Estadual Paulista - UNESP - FMVZ
} 


\section{INTRODUCTION}

Several etiological agents may be present in cattle herds with a history of abortion, including Neospora caninum (N. caninum), Brucella abortus (B. abortus), Bovine Herpesvirus Type 1 (BHV-1) and Leptospira spp. The $N$. caninum protozoan has been touted as one of the most important causes of abortion in dairy sheep from different countries (GONDIM et al., 2004). Transplacental transmission is the most common form of infection of cattle (GUIMARÃES JUNIOR \& ROMANELLI, 2006).

Bovine brucellosis is a highly transmissible worldwide zoonosis caused by Brucella abortus (B. abortus). Most European countries and other major beef exporters such as Australia, Canada and New Zealand are classified as free of this disease or are in the process of elimination as the United States and India (OIE, 2012). Transmission occurs primarily by ingestion of contaminated food and water; however, it can also occur by inhalation, conjunctival inoculation, fomites and skin wounds (CORBEL et al., 2006).

The Bovine Herpesvirus Type 1 (BHV-1) is the agent responsible for infectious bovine rhinotracheitis (IBR). The virus establishes a latent infection in sensory ganglia. Infected animals become non-apparent carriers with sporadic episodes of viral re-excretion and potential source of transmission (JONES, 2003). The transmission happens mainly through direct contact with nasal and ocular secretions, aerosols, semen, vaginal secretions and fluids and fetal tissues of infected animals, or indirectly via fomites (NANDI et al., 2009).

Leptospirosis is a worldwide zoonosis. From the epidemiological point of view, it is important to know the prevalent serovars in a given region (MARINHO, 2008) while wolffi and hardjo are the most commonly found in São Paulo state (FAVERO et al., 2001). The microscopic agglutination test (MAT) is the recommended method of serological diagnosis for leptospirosis according to the World Organization for Animal Health (OIE, 2013a). Given the importance of concomitant infections that cause reproductive losses in dairy cattle, the aim of this study is to conduct an epidemiological survey to evaluate the losses of the dairy herd in a farm in São Carlos-SP region due to abortions and stillbirths, as well as determine the positivity of the animals for Neospora caninum, Brucella abortus, BHV-1 and Leptospira spp., in order to help the decision making process to adopt measures for disease control and prevention.

\section{MATERIAL AND METHODS}

The study was conducted at the Division of Milk Production at the Experimental Unit of EMBRAPA Pecuária Sudeste, located in São Carlos, SP, Brazil. The herd of dairy cows consists of Holstein and crossbred Holstein-Jersey, containing on average 274 animals. The 142 animals used in this study were at reproductive age, between two and 8.6 years, of which $14.8 \%$ ( 21 animals) had had miscarriages in at least one pregnancy and $8.5 \%$ (12 animals) had recently aborted (during 2011).

It is noteworthy that this herd is for reproductive management; therefore, all females are subjected to artificial insemination with cryopreserved commercial semen. In addition, the animals are vaccinated against IBR at twelve months old, with a booster after 30 days and subsequently, every year during May and November using inactivated vaccines. The heifers are vaccinated against brucellosis between four and six months old with sample of B. abortus B19. Vaccination against leptospirosis consists of inactivated vaccines given every four months, in September, January and May from one year old against the serovars hardjo, wolffi, pomona, icterohaemorrhagiae, grippotyphosa and canicola. Cows that abort are treated with streptomycin in a single dose regardless of the agent. Vaccinations for neosporosis prevention are not carried out.

On the first day of March 2012, blood samples were collected from all cows older than two years old (142 animals). The blood was drawn by puncture of the jugular vein with disposable needles and vacuum systems, in sterile tubes. After coagulation, blood was centrifuged at $350 \mathrm{~g}$ for 10 minutes to separate the serum. The material was labeled, packed in sterile 2-ml microcentrifuge tubes and stored at $-20^{\circ} \mathrm{C}$ until analysis.

The serological tests for the diagnosis of antiNeospora caninum antibodies were performed at the Laboratory of Zoonoses, Department of Veterinary Hygiene and Public Health, Faculdade de Medicina Veterinária e Zootecnia, UNESP, Botucatu, by indirect immunofluorescence assay (IFA). The secondary antibody used was anti-bovine $\mathrm{IgG}$ conjugated to fluorescein, FITC (Affinity Purified Antibody Fluorescein, 910 Clopper Road, Gaithersburg, MD 20878 USA. www.kpl.com). Serum samples were positive when complete fluorescence was observed on the $N$. caninum tachyzoite surface, in the 1:25 dilution. The positive samples were subjected to serial dilutions up to $1: 6400$, thereby determining antibodies titer. The titration cutoff value of 100 was used.

Buffered Acidified Antigen test to diagnose anti-Brucella abortus antibodies was performed at the Laboratory of Animal Health of EMBRAPA Pecuária Sudeste. A sample consisting of $30 \mu \mathrm{L}$ bovine blood serum mixed with $30 \mu \mathrm{L}$ of buffered acidified antigen was stirred for four minutes to mix well and observed under a light beam (BRAZIL, 2006).

The serological tests for the diagnosis of antiBHV-1 antibodies were performed by virus neutralization (VN) micro-technique at the Serologic Diagnosis laboratory of the Setor de Viroses da Reprodução of the Departamento de Medicina Veterinária Preventiva e Reprodução Animal, UNESP, Jaboticabal, SP. The MDBK (Madin Darby Bovine Kidney) cells used had 200 TCID $_{50}$ of the Los Angeles BHV-1virus prototype. The incubation of virus/serum was completed in one hour at $37^{\circ} \mathrm{C}$ in a $5 \% \mathrm{CO}_{2}$ environment, following the methodology described by 
the OIE (2013b). The final reading was taken at the end of 72 hours. The reaction end point was determined by the highest serum dilution able to inhibit $100 \%$ of the cytopathic effect induced by BHV-1 in MDBK cells. Since the animals were vaccinated against BHV-1, a titration cut off value of 256 was used, as recommended by Pospisil (1996).

Serologic tests to diagnose leptospirosis were performed by the Microscopic Agglutination Test technique at the Departamento de Medicina Veterinária Preventiva e Reprodução Animal of the UNESP, Jaboticabal, SP, according to the recommendations of the OIE (2013a). Initially, the samples were screened for the serovars australis, bratislava, autumnalis, butembo, castellonis, bataviae, canicola, whitcomb, cynopteri, fortbragg, grippotyphosa, hebdomadis, copenhageni, icterohaemorrhagiae, panama, pomona, pyrogenes, hardjo, wolffi, shermani, sentot and tarassovi. Reagent samples were able to agglutinate $50 \%$ or more of the live Leptospira contained in the $1 / 100$ dilution of the antigen solution (HASHIMOTO et al., 2012). Subsequently, the reagent samples were serially diluted by a factor of two and tested to define the final antibody titer for each biovar. Reading of the agglutination reactions was performed in dark field microscope. The animals with titers of more than one serovar were ranked according to the highest titer.

The epidemiological study to determine the reproductive losses and prevalence of abortions and stillbirths that occurred in the dairy herd during 2011 used the existing data between January 2006 and December 2011. The criteria used to establish the normal level was the mean \pm standard deviation method applied to the time series obtained by the incidence rate during the years from 2006 to 2010, according to Cortes (1993). The confidence level for the calculation was $95 \%$.

Data were analyzed using EpiInfo version 7.1.1.14 software (EPI INFO ${ }^{\mathrm{TM}}$ 7.1.1.14, 2013). The relative risk (RR) was calculated between the studied diseases and reproductive failure. To determine the statistical significance of the calculations, the $95 \%$ significance level was used $(95 \% \mathrm{CI})$ of the OR and $\mathrm{RR}$, and the corrected chi-square test. The Fisher exact test replaced the corrected chi-square test $(\mathrm{P} \leq 0.05)$ when necessary. The association between the presence of antibodies and reproductive failure was established if considered statistically significant and the number 1 was not part of the $95 \%$ CI. Causality was suggested if all $95 \%$ CI was larger than 1.

\section{RESULTS AND DISCUSSION}

The intensive management practices used in dairy cattle farms can facilitate the transmission of various infectious diseases (MEDICI et al., 2000). Between the months of January 2006 and December 2011 there was a monthly average of 1.7 abortions and 0.7 stillbirths, totaling 122 abortions and 50 stillbirths in the herd studied. Most abortions (63.6\%) and stillbirths $(58 \%)$ observed in the period occurred between November and April (the rainfall season in the region). Moisture is necessary for the maintenance of viable micro-organisms in the environment.

Figure 1 shows the epidemiological curve established for the year 2011. No epidemic was recorded in the period. During April and September, the number of abortions and stillbirths were below the lower limit. In the studied herds, no animals were bought during the period. The endemic behavior of reproductive losses associated with possible contact of animals with etiologic agents during the years prior to the study period may favor the development of herd immunity so that reproductive losses were kept within a normal range. This behavior is not observed when an exotic disease enters a population. Of the miscarriages observed in the studied herd during the six years analyzed, $76.2 \%$ occurred in the middle third of pregnancy, $15 \%$ in the final third and $8.8 \%$ in the first third. Abortions and stillbirths may represent a great reduction of milk production throughout the cow life and result in large losses to the farmer. Dubey and Schares (2011) also indicate as abortion-related losses: the cost of veterinary care, diagnosis, replacement and discarding of animals, longer periods of service and subsequent calving intervals.

According to Dubey (2003), among the clinical signs of bovine neosporosis, embryonic death during the first third of pregnancy and abortion in the second are the most common. Infection, when it occurs in the last third of gestation, is unlikely to result in fetal death and abortion, but may result in birth of persistently infected calves, something that can also occur in the second third.

The indirect immunofluorescence serological tests to diagnose anti-Neospora caninum antibodies showed that $48.6 \%$ of the animals were seropositive, and $28.9 \%$ had greater than or equal to 100 (Table 1) titer. Of the cows with a history of miscarriages or stillbirths (29 animals), 44.8\% (13 animals) were serum reactive. The lowest titer observed was 25 , whereas the highest was 400. There is a positive correlation between animals that had miscarriages or stillbirths in 2011 (14 animals) and seropositivity for anti-Neospora caninum (Table 2) antibodies. The presence of $N$. caninum seropositive cows in the herd shows that there was contact with the infectious agent; however, it is not possible to correlate it with reproductive losses during the period studied.

Hein et al. (2012) reported opposite results for a cutoff value of 1:200 in indirect immunofluorescence. They observed a $58.5 \%$ seropositive frequency to $N$. caninum in animals with a history of miscarriages. Serological studies showed that cows positive for $N$. caninum were 2 to 7.4 times more likely to have a history of miscarriage.

The occurrence of anti-N. Caninum antibodies in this study was higher than that reported by Muñoz et al. (2006) and Ragozo et al. (2003), suggesting a greater exposure to the causative agent in the studied farm, probably due to the lack of specific measures to prevent and control neosporosis. On the other hand, Martins et al. (2011) used the titer cutoff value of 200 in the IFAT and obtained $25 \%$ of IgG anti-N.caninum 


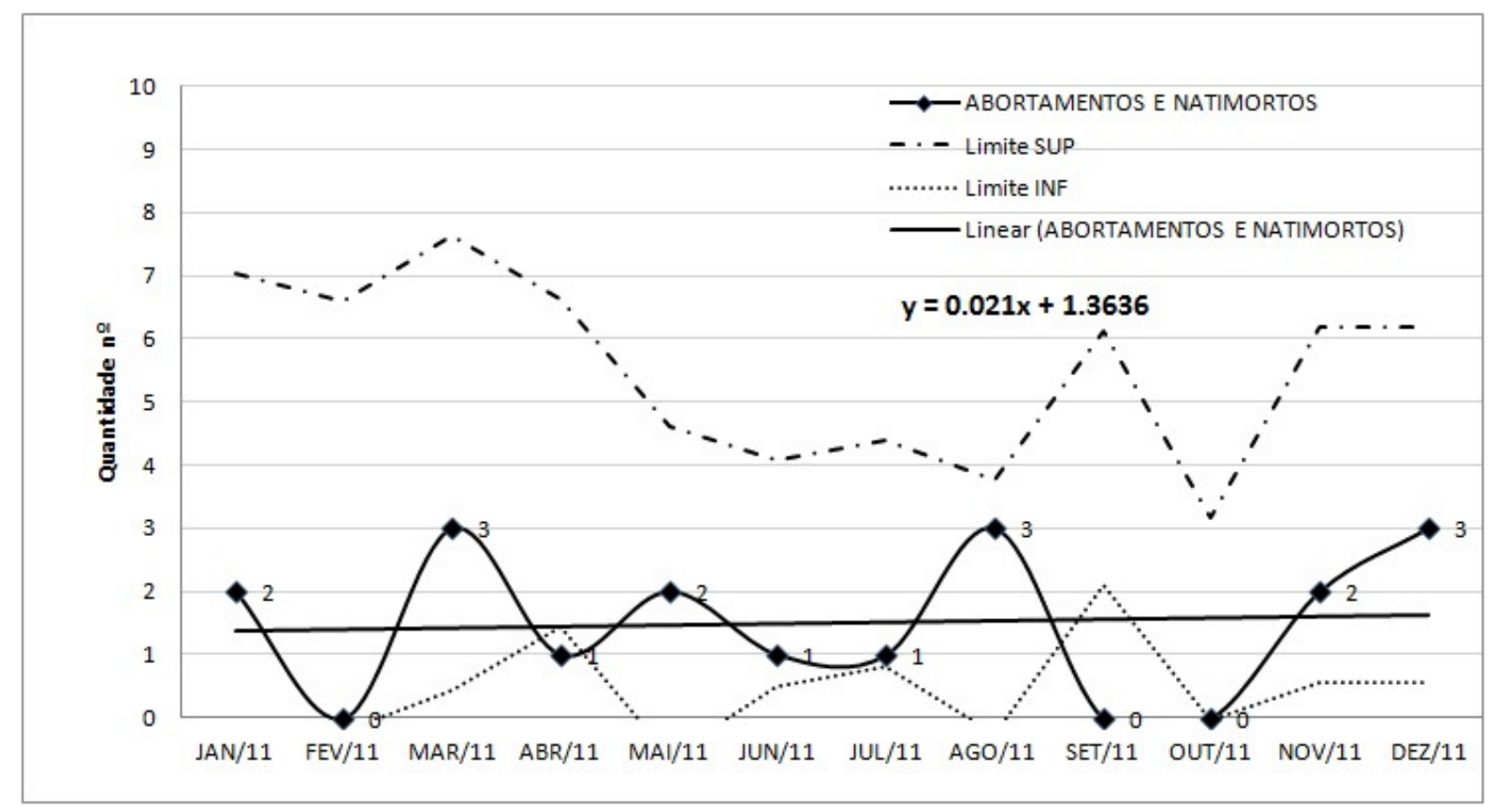

Figure 1 - Epidemiological curve of reproductive losses in a dairy cattle herd. São Carlos, 2006-2011. SUP: Upper Control Limit $(\mathrm{x}+\mathrm{s})$; INF: lower control limit $(\mathrm{xs})$; Linear: linear data fitting (equation: $\mathrm{y}=0.021 \mathrm{x}+1.3636$ ).

Table 1 - IFAT Titers for anti-N. caninum in a dairy cattle herd. São Carlos, March 1, 2012.

Titration

\begin{tabular}{lccc} 
& $<25$ & $>25$ and $<100$ & $\geq 100$ \\
\cline { 2 - 4 } & $11(7.7 \%)$ & $5(3.5 \%)$ & $13(9.2 \%)$ \\
Abort. Stillbirth $^{1}$ & $62(43.7 \%)$ & $23(16.2 \%)$ & $28(19.7 \%)$ \\
\hline Tealthy & $73(51.4 \%)$ & $28(19.7 \%)$ & $41(28.9 \%)$ \\
\hline
\end{tabular}

${ }^{1}$ Animals with a history of miscarriages or stillbirths in at least one pregnancy between 2006 and 2011.

${ }^{2}$ Animals with no history of miscarriages or stillbirths.

Table 2 - Correlation between positive IFAT for anti-N. caninum and recent reproductive losses.

\begin{tabular}{|c|c|c|c|c|c|c|c|}
\hline \multirow{3}{*}{$\begin{array}{c}\text { Agent } \\
\text { N. caninum }\end{array}$} & \multirow{2}{*}{$\begin{array}{l}\text { Cutoff } \\
100\end{array}$} & \multicolumn{2}{|c|}{ Animals } & \multirow[b]{2}{*}{$\mathrm{Ct}$ (no.) } & \multirow[b]{2}{*}{ RR } & \multirow[b]{2}{*}{ CI (95\%) } & \multirow[b]{2}{*}{ P. } \\
\hline & & Condition & $\begin{array}{l}\text { Abt./stillb. } \\
\text { (no.) }\end{array}$ & & & & \\
\hline & 100 & $\begin{array}{l}\text { Positive } \\
\text { Negative }\end{array}$ & $\begin{array}{c}10 \\
4\end{array}$ & $\begin{array}{l}59 \\
69\end{array}$ & 2.644 & 0.87 & 0.128 \\
\hline
\end{tabular}

P. = Probability calculated by Yates corrected Chi-square; Ab./stillb. $=$ Animals that aborted or had stillbirths in 2011; Ct $=$ Animals that neither aborted nor had stillbirths in 2011, RR = relative risk, $\mathrm{CI}=$ confidence interval of $95 \%$.

antibodies in a total of 192 samples from lactating cows of ten small dairy farms located in the microAraguaína region of Tocantins.

The elimination of seropositive animals, acquiring negative animals, the proper disposal of aborted fetuses and placental membranes, controlling dogs and other carnivorous animals' access to the herds are control measures that may help avoid possible economic losses (HEIN et al., 2012).

The buffered acidified antigen tests performed to diagnose $B$. abortus did not have positive reactions in the present study. In the studied herds, the entry of the bacteria was hindered due to fact that no animals were acquired; calves were separated from their 
mothers on the first day of life; vaccination against brucellosis with the B19 vaccine was performed between four and six months of life; and, the management where young animals were separated from adults until the reproductive age. New tests should be performed in the entire herd at time intervals determined by the National Program for the Control and Eradication of Animal Brucellosis and Tuberculosis (BRAZIL, 2006) to confirm the absence of the etiologic agent in the herd, thus certifying the farm as free of the diseases.

The virus neutralization tests (Table 3) showed the presence of anti-BHV-1 antibodies in $97.9 \%$ of samples while $26.8 \%$ of the animals that were positive had titers greater than or equal to 256 . Of the cows with a history of miscarriages or stillbirths (29 animals), $41.4 \%$ (12 animals) were serum reactive for the titer cutoff value (256). There was a positive association with confidence interval higher than 1 , between animals with cases of miscarriages or stillbirths and serum positivity for anti-BHV-1; however, it was not statistically significant by Fisher's exact test (Table 4). These results may suggest a significant contribution of BHV-1 in the reproductive failures observed in the studied herd.

For the cows that had virus neutralization titers, the lowest titers were observed at the 1:2 dilutions while the highest were equal to or higher than 1:1024 dilution.

Medici et al. (2000) studied a dairy cattle herd in Paraná, and reported that $39.3 \%$ were positive when analyzing only animals with reproductive disorders and $43.2 \%$ when analyzing the whole flock. These authors used as a cutoff point the inhibition of cell lysis at 1:4 dilutions in virus neutralization. The results obtained by Médici et al. (2000) were higher than those presented in this study; however, the cutoff may have caused this disagreement. Sousa et al. (2009) studied the dairy region of the island of São Luís, MA, and found that $67.5 \%$ of samples of non-vaccinated dairy cows had antibodies against BHV-1.

The presence of anti-BHV-1 titers in almost all animals studied in this work is probably due to the vaccination management with inactivated vaccines, which tend to generate low titers (usually less than 256). Due to the latency of infection and high frequency, an eradication program should be studied in detail since discarding the infected animals can be economically impracticable; therefore, preventive and control measures can be intensified in order to reduce the rate of infected animals.

Regardless of infection pressure, the correct management of the herd can lessen the spread of BHV1. Minimizing stress during handling, reducing the contact of calves with adult animals at the stage when passive colostral immunity finishes, avoiding constant turnover with the introduction of susceptible or infected animals in the farm and reducing the high density of animals are preventive and control measures that lower the rates of infections (GATTI et al., 2010).

In the microscopic agglutination test (Table 5), only $7.7 \%$ of the studied animals had titers equal to or greater than 100. Only one animal with history of abortion did not have negative serology (titer of 100). There is no correlation between reproductive losses and greater than or equal to 100 titers to Leptospira spp. in the studied animals, including wolffi and pomona serovars (Table 6).

The most prevalent serovars in reagent animals were: pomona $(63.3 \%)$, hardjo $(45.5 \%)$, tarassovi $(27.3 \%)$ and wolffi $(9.1 \%)$. Of the animals considered positive, five $(45.5 \%)$ had antibodies against two serovars and four of them had reactions against hardjo serovar.

The only cow with a history of abortion, and positive serology for leptospirosis, was reactive for the serovar pomona in the $1 / 100$ dilution. The low percentage of animal seropositive against Leptospira spp. reagents may have been influenced by the routine management of administering intramuscular streptomycin in cows after abortion without identifying the cause.

\section{CONCLUSION}

This work suggests the presence of BHV-1, N. caninum and Leptospira spp. in contact with the dairy cows of the experimental farm. The first etiologic agent is the most important due to the direct correlation with the occurrence of abortions and stillbirths in the herd. The epidemiological study shows that reproductive losses in the cattle are endemic, which could imply possible behavior of chronic infections caused by these microorganisms. The etiological agents studied may be acting alone or in concurrent infections in animals. Periodic serological evaluation of the herd is critical to help the introduction of preventive and control measures.

Table 3 - Serum neutralization titers for anti-BHV-1 in a dairy cattle herd. São Carlos, March 1, 2012.

\begin{tabular}{lccc} 
& \multicolumn{3}{c}{ Titration } \\
\cline { 2 - 4 } & $<2$ & $>2$ and $<256$ & $\geq 256$ \\
\hline Abort./stillbirth $^{1}$ & $1(0.7 \%)$ & $16(11.3 \%)$ & $12(8.5 \%)$ \\
Healthy $^{2}$ & $2(1.4 \%)$ & $85(59.8 \%)$ & $26(18.3 \%)$ \\
\hline TOTAL & $3(2.1 \%)$ & $101(71.1 \%)$ & $38(26.8 \%)$ \\
\hline
\end{tabular}

${ }^{1}$ Animals with a history of miscarriages or stillbirths in at least one pregnancy between 2006 and 2011.

${ }^{2}$ Animals with no history of miscarriages or stillbirths. 
Table 4 - Correlation between positive SN for anti-BHV-1 and recent reproductive losses.

\begin{tabular}{ccccccccc}
\hline \multirow{2}{*}{ Agent } & Cutoff & Condition & $\begin{array}{c}\text { Abt./stillb. } \\
\text { (no.) }\end{array}$ & $\begin{array}{c}\mathrm{Ct} \\
\text { (no.) }\end{array}$ & & RR & CI (95\%) & P. \\
\cline { 3 - 8 } IBR & 256 & Positive & 7 & 31 & 2.736 & 1.027 & 7.289 & 0.054 \\
\cline { 3 - 8 } & & Negative & 7 & 97 & &
\end{tabular}

$\mathrm{P}=$ Probability calculated by Fisher exact test; Ab./stillb. = Animals that aborted or had stillbirths in $2011 ; \mathrm{Ct}=$

Animals that neither aborted nor had stillbirths in 2011; RR = relative risk; $\mathrm{CI}=$ confidence interval of $95 \%$.

Table 5 - MAT titers for anti-Leptospira spp. in a dairy cattle herd. São Carlos, March 1, 2012.

Titration

\begin{tabular}{lcc} 
& $<100$ & $\geq 100$ \\
\cline { 2 - 3 } Abort./Stillbirth $^{1}$ & $28(19.7 \%)$ & $1(0.7 \%)$ \\
Healthy $^{2}$ & $103(72.5 \%)$ & $10(7.0 \%)$ \\
\hline TOTAL & $131(92.3 \%)$ & $11(7.7 \%)$ \\
\hline
\end{tabular}

${ }^{1}$ Animals with a history of miscarriages or stillbirths in at least one pregnancy between 2006 and 2011.

${ }^{2}$ Animals with no history of miscarriages or stillbirths.

Table 6 - Correlation between positive MAT for anti-Leptospira spp. and recent reproductive losses.

\begin{tabular}{|c|c|c|c|c|c|c|c|c|}
\hline \multirow[b]{3}{*}{ Abt./stillb. (no.) } & \multirow{3}{*}{$\begin{array}{l}\text { Cutoff } \\
\text { Ct (no.) }\end{array}$} & \multicolumn{7}{|c|}{ Animals } \\
\hline & & Condition & $\begin{array}{c}\text { Abt./stillb. } \\
\text { (no.) }\end{array}$ & $\mathrm{Ct}$ (no.) & RR & & & P. \\
\hline & & $\begin{array}{l}\text { Positive } \\
\text { Negative }\end{array}$ & $\begin{array}{c}0 \\
14\end{array}$ & $\begin{array}{c}11 \\
117\end{array}$ & 0.0 & - & - & 0.60 \\
\hline Wolffi & 100 & $\begin{array}{l}\text { Positive } \\
\text { Negative }\end{array}$ & $\begin{array}{c}0 \\
14\end{array}$ & $\begin{array}{c}5 \\
123\end{array}$ & 0.0 & - & - & 1.00 \\
\hline Pomona & 100 & $\begin{array}{l}\text { Positive } \\
\text { Negative }\end{array}$ & $\begin{array}{c}0 \\
14\end{array}$ & $\begin{array}{c}7 \\
121\end{array}$ & 0.0 & - & - & 1.00 \\
\hline
\end{tabular}

P. = Probability calculated by Fisher exact test; Ab./stillb. $=$ Animals that aborted or had stillbirths in $2011 ; \mathrm{Ct}=$ Animals that neither aborted nor had stillbirths in 2011; RR = relative risk, $\mathrm{CI}=$ confidence interval of $95 \%$.

\section{REFERENCES}

BRASIL, Ministério da Agricultura, Pecuária e Abastecimento. Secretaria de Defesa Agropecuária Departamento de Saúde Animal. Programa Nacional de Controle e Erradicação da Brucelose e Tuberculose Animal (PNCEBT): manual técnico, Brasília, 2006, 188p.

CORBEL, M. J.; ARIZA, J.; BANAI, M.; COSIVI, O.; DIAZ, R.; DRANOVSKAYA, E. A.; ELBERG, S. S.; GARIN-BASTUJI, B.; KOLAR, J.; MacMILLAN, A.
P.; MANTOVANI, A.; MORIYON, I.; MOUSA, A.; NICOLETTI, P.; SEMEINIS, A.; YOUNG, E. J. Brucellosis in humans and animals. World Health Association. Genova, Suiça, c.2-4 (anexo 6) p.3-35, 2006.

CÔRTES, J. A. Formas de ocorrência de doenças em populações. IN: Côrtes, J.A. Epidemiologia: conceitos e princípios fundamentais. Livraria Varela, c.11, p.116-117, 1993. 
DUBEY, J. P. Review of Neospora caninum and neosporosis in animals. Korean Journal of Parasitology, v.41, p.1-16, 2003.

DUBEY, J. P.; SCHARES, G. Neosporosis in animals: The last five years. Veterinary Parasitology, v.180, p.90-108, 2011.

EPI INFOTM ${ }^{\mathrm{TM}}$ 7.1.1.14. Center for Disease Control and Prevention, Atlanta, GA, 2013. Disponível em: <http://wwwn.cdc.gov/epiinfo/html/downloads.htm> FAVERO, M.; PINHEIRO, S.R.; VASCONCELLOS, S.A.; MORAIS, Z.M.; FERREIRA, F.; FERREIRA NETO, J.S. Leptospirose bovina - variantes sorológicas predominantes em colheitas efetuadas no período de 1984 a 1997 em rebanhos de 21 estados do Brasil. Arquivos do Instituto Biológico, São Paulo, v.68, n.2, p.29-35, 2001.

GATTI, S. P.; AFFONSO, I. B.; DIAS, F. C.; MEDEIROS, A. S. R.; FERREIRA, F.; SAMARA, S. I. Titulos de anticorpos anti-Herpesvírus Bovino Tipo 1 (BoHV-1) de bezerras em três rebanhos leiteiros do estado de São Paulo, Brasil. ARS Veterinária, v.26, n.3, p.147-152, 2010.

GONDIM, L. F. P.; McALLISTER, M. M.; PITT, W. C.; ZEMLICKA, D. E. Coyotes (Canis latrans) are definitive hosts of Neospora caninum. International Journal for Parasitology, v.34, p.159-161, 2004.

GUIMARÃES JÚNIOR, J. S.; ROMANELLI, P. R. Neosporose em animais domésticos. Semina: Ciências Agrárias, v.27, p.665-678, 2006.

HASHIMOTO, V. Y.; DIAS, J. A.; SPORH, K. A. H.; SILVA, M. C. P.; ANDRADE, M. G. B.; MÜLLER, E. E.; FREITAS, J. C. Prevalência e fatores de risco associados à Leptospira spp. em rebanhos bovinos da região centro-sul do estado do Paraná. Pesquisa Veterinária Brasileira, v.32, n.2, p.99-105, 2012.

HEIN, H. E.; MACHADO, G.; MIRANDA, I. C. S.; COSTA, E. F.; PELLEGRINI, D. C. P.; DRIEMEIER, D.; CORBELLINI, L. G. Neosporose bovina: avaliação da transmissão vertical e fração atribuível de aborto em uma população de bovinos no Estado do Rio Grande do Sul. Pesquisa Veterinária Brasileira, v.32, n.5, p.396-400, 2012.

JONES, C. 2003. Herpes simplex virus type 1 and bovine herpesvirus 1 latency. Clinical Microbiology Reviews, v.16, n.1, p.79-95, 2003.

MARINHO, M. Leptospirose: fatores epidemiológicos fisiopatológicos e imunopatogênicos. Revista Veterinária e Zootecnia, v.15, n.3, p.428-434, 2008.

MARTINS, N. E. X.; FRESCHI, C. R.; BAPTISTA, F.; MACHADO, R. Z.; FREITAS, F. L. C.;
ALMEIDA, K. S. Ocorência de anticorpos antiNeospora caninum em vacas lactantes do município de Araguaíana, estado do Tocantins, Brasil. Revista de patologia Tropical, v.40, n.3, p.231-238, 2011.

MÉDICI, K. C.; ALFIERI, A. A.; ALFIERI, A. F. Prevalência de anticorpos neutralizantes contra o Herpesvírus Bovino Tipo 1, decorrente de infecção natural, em rebanhos com distúrbios reprodutivos. Ciência Rural, v.30, n.2, p.347-350, 2000.

MUNHOZ, A. D.; SINO, W. F.; DA SILVA, R. T.; DE ALMEIDA, C. R. R.; LOPES, C. W. G. Distribuição de anticorpos contra Neospora caninum em vacas leiteiras dos municípios de Resende e Rio Claro, estado do Rio de Janeiro Brasil. Revista Brasileira de Parasitologia Veterinária, v.15, n.3, p.101-104, 2006.

NANDI, S.; KUMAR, M.; MANOHAR, M.; CHAUHAN, R.S. Bovine herpes vírus infection in cattle. Animal Health Research Reviews. Cambridge, n.10 (1), p.85-98, 2009.

OIE. Manual of diagnostic test and vaccines for terrestrial animals 2012. CHAPTER 2.1.9. (Version adopted by the World Assembly of Delegates of the OIE in May 2010). Disponível em: http://www.oie.int/fileadmin/Home/eng/Health_standar ds/tahm/2.01.09_LEPTO.pdf >. Acesso em: 20/05/2013a.

OIE. Manual of diagnostic test and vaccines for terrestrial animals 2012. CHAPTER 2.4.13 (Version adopted by the World Assembly of Delegates of the OIE in May 2010). Disponível em: http://www.oie.int/fileadmin/Home/eng/Health_standar ds/tahm/2.04.13_IBR_IPV.pdf>. Acesso em: 24/05/2013b.

OIE. WAHID INTERFACE. Disponível em: $<$ http://web.oie.int/wahis/public.php?

page $=$ disease_status_lists $>$. Acesso em: 02/04/2012 POSPISIL, Z.; KERJCI, J.; JINEK, P.; LÁNY, P.; ZENDULKOVÁ, D.; CÍHAL, P. Development of a disease control program based on the use of an inactivated vaccine against infectious bovine rhinotracheitis. Veterinary Microbiology, v.38, n.4, p.199-206, 1996.

RAGOZO, A. M. A.; PAULA, V. S. O.; SOUZA, S. L. P.; BERGAMASCHI, D. P.; GENNARI, S. M. Ocorrência de anticorpos anti-Neospora caninum em soros bovinos procedentes de seis estados brasileiros. Revista Brasileira de Parasitologia Veterinária, v.12, n.1, p.33-37, 2003.

SOUSA, V. E.; BEZERRA, D. C.; CHAVES, N. P.; SANTOS, H. P.; PEREIRA, H. M. Frequência de anticorpos contra o Herpesvírus Bovino Tipo 1 (BHV1) em bovinos leiteiros não vacinados na bacia leiteira 
da ilha de São Luis-MA. Ciência Animal Brasileira -

Suplemento 1, 2009 - Anais do VIII Congresso

Brasileiro de Buiatria. 